\title{
Escaping Social Injustices: Changemaking Escape Rooms for Human Rights in the Literature Classroom
}

\author{
Emily Andrea Sendin \\ Faculty English, Miami Dade College - Eduardo J. Padrón Campus \\ (i)/0000-0001-5827-0343
}

DOI: https://dx.doi.org/10.46679/978819484836305

\section{Abstract}

Escape rooms have been used in STEM classrooms, but there is little evidence of successful implementation of escape rooms in humanities courses in higher learning. This paper examines the experience of adapting escape rooms for the education setting in literature. To do so, two new components in the learning process were incorporated: (a) students are required to create their own escape rooms, thus increasing the stakes and the level of ownership; they are not only responsible for their own learning, but they also need to teach others; and, (b) students are required to explore a human rights violation or social injustices in their escape rooms, making civic engagement an end goal of the project. Participants in their escape room come out of the experience learning something about social change and being called to action.

Keywords: escape rooms, literature, social justice, higher education, digital escape rooms 
Figure 1

Department of Magic Escape Room

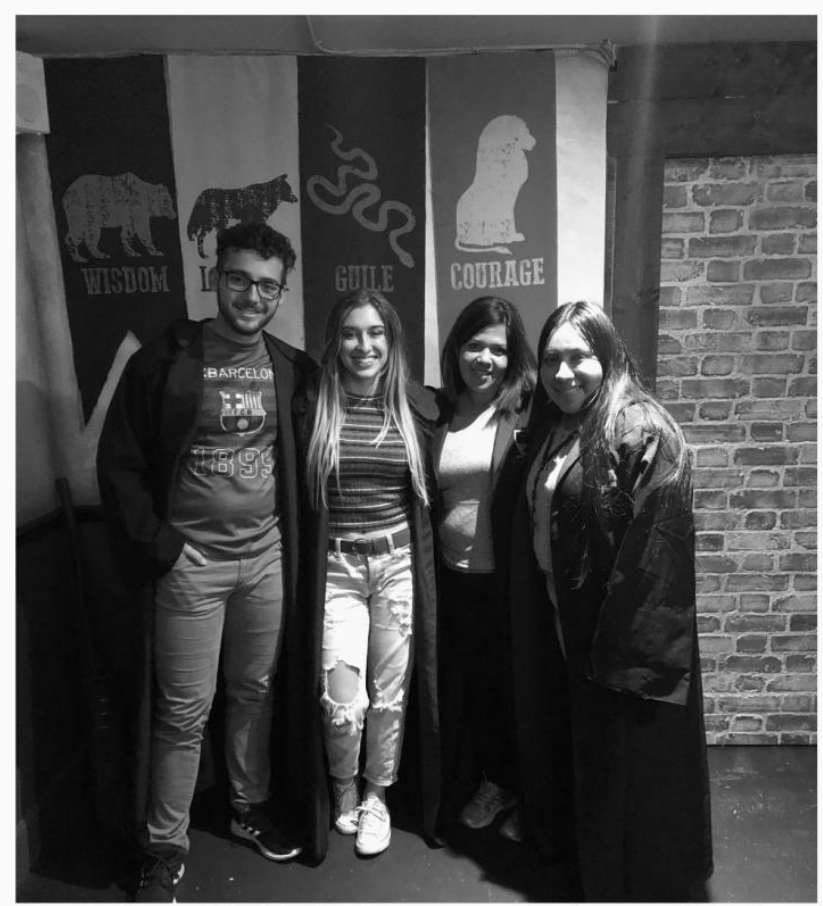

Note. Students and I, with wizard robes on, prepared to enter Harry Potter escape room in Edinburgh, Scotland. Students image used with permission.

\section{Introduction}

Protecting the world from Voldemort is no easy task. However, my students were up to the challenge in 2019 during the Issues of Literature and Culture study abroad in England, Scotland, and Croatia - a course envisioned and developed with Harry Potter, Outlander, and Game of Thrones themes.

In Edinburgh, Scotland, students participated in a Harry Potter escape room. This was my first experience witnessing the power of escape rooms as educational tools. At the Department of Magic, a sort of mix between café, pub, game room, and waiting room, my students and I created our own potions inspired by the Harry Potter series while we waited to enter the magical room we would eventually need to escape. Before embarking on our adventure, we were separated into groups of four and required to put away all electronic devices; the only tools we could use were ourselves and our teammates. As a participant, I did not have much time to be a spectator. I fully immersed myself in the goal of escaping within the allotted time, 50 minutes. 


\section{This is a limited preview of the chapter.}

To read the full-text chapter, get access by purchasing this chapter or consider buying the complete book. If your library has subscription to EBSCOhost, the chapter including other chapters of the book can be accessed through your library.

This chapter is a part of the book, 'Development of Innovative Pedagogical Practices for a Modern Learning Experience' ISBN (paperback): 978-81948483-6-3; ISBN (ebook): 978-81-948483-7-0

Book DOI: https://dx.doi.org/10.46679/9788194848363

Available via CSMFL Bookstore, Amazon, Google Play Books, EBSCOhost \& EBSCO eBooks 
classroom to my students. Being fearless involves deep trust in students and innovative teaching and learning. I have always framed this experience for my students as an experiment. The future of successful escape room pedagogical practices is dependent on continuous experimentation and research. As I witness success from my budding escape room artists, higher retention and passing rates, and I experience laughter and joy in my Zoom classrooms, I am grateful for digital escape rooms during a year where most of my students needed something different and fun to keep their minds off social distancing, quarantine, unemployment, and friends and family losses. Most importantly, I am creating social justice warriors one escape room at a time.

\section{References}

Department of Magic (2021). Cast your spells. Department of Magic Escape Room Edinburgh.

https://www.departmentofmysteries.com/

Dobbs, M. (n.d.). How to build a digital escape room using Google forms - Bespoke ELA: Essay Writing Tips + Lesson Plans. Bespoke ELA. https://www.bespokeclassroom.com/blog/2019/10/4/how -to-build-a-digital-escape-room-using-google-forms

Gómez López, A. (2019). The use of escape rooms to teach and learn English at the university. In S. Pérez-Aldeguer \& D, Akombo (Eds.), Research, technology and best practices in education. (pp. 94102). Adaya Press.www.adayapress.com/wpcontent/uploads/2019/07/RTb9.com

Kuh, G. D. (2008). High-impact educational practices: What they are, who has access to them, and why they matter. Online Excerpt. Association of American Colleges and Universities. [web log].https://www.aacu.org/node/4084

Lafontaine, C., Sawchuk, K., \& DeJong, S. (2020). Social justice games: Building an escape room on elder abuse through participatory 
action research. Computer Games Journal, 9, 189-205.

https://doi.org/10.1007/s40869-020-00105-5

Lee, J. J., \& Hammer, J. (2011). Gamification in education: What, how, why bother? Academic Exchange Quarterly, 15(2), 1-5. https://www.researchgate.net/publication/258697764_Gamifica tion_in_Education_What_How_Why_Bother

López-Pernas, S., Gordillo, A., Barra, E., Quemada, J. (2019). Examining the use of an educational escape room to teach programming in a higher education setting. Universidad Politécnica de Madrid,7, 31323-31737. https://doi.org/10.1109/ACCESS.2019.2902976

Lovgreen, T. 2017). Escape room designed by charity replicates barriers faced by homeless. CBC News.

[video]https://www.cbc.ca/news/canada/britishcolumbia/escape -room-homelessness-barriers-1.4342753

Melo, M., \& Johnson, A (2018). Teaching technical writing through designing and running escape rooms. Dialogue: The Interdisciplinary Journal of Popular Culture and Pedagogy,5(2). 1-13. http://journaldialogue.org/v5-issue-2/teaching-technicalwriting-through-designing-and-running-escape-rooms/ Miami Dade College (2021). Enrollment Management. Strategy and Institutional Effectiveness.

https://www.mdc.edu/ir/iremployees/enrollment_managemen $\mathrm{t} /$ index.aspx

Myers, Z. (n.d.) Global Goals Game. Breakout EDU. https://platform.breakoutedu.com/ game/global-goals

Nicholson, S. (2015). Peeking behind closed doors: A survey of escape room facilities. White paper available online at http://scottnicholson.com/pubs/erfacwhite.pdf

Nicholson, S. (2018). Creating engaging escape rooms for the classroom. Childhood Education, 94(1). 44-49. Available online at http://scottnicholson.com/pubs/ escapegamesclassroom.pdf 
Rouse, W. (2017). Lessons learned while escaping from a zombie:

Designing a breakout EDU game. The History Teacher: The Society for History Education,50(4), 553-563. http://works.bepress.com/wendy_rouse/28/

Spira, L. (2019, May 27). The privilege of escape: Interview with artist \&game designer Risa Puno. Room Escape Artist. https://roomescapeartist.com/2019/05/24/privilege-escapeinterview-risa-puno/

Ouariachi, T., \& Wim, E. J. L. (2020). Escape rooms as tools for climate change education: An exploration of initiatives. Environmental Education Research. 25(12). https://doi.org/10.1080/13504622.2020.1753659

United Nations (n.d.) The 17 Goals: Sustainable development. United Nations. https://sdgs.un.org/goals

Whitton, N. (2018). Playful learning: Tools, techniques, and tactics. Research in Learning Technology, 26. https://doi.org/10.25304/rlt.v26.2035

\section{About the author}

Emily Andrea Sendin is a professor of English, literature, and creative writing in her twenty-second year teaching at Miami Dade College. Professor Sendin is an Endowed Teaching Chair and Fulbright Scholar. She teaches Global Sustainability and Earth Literacy Studies, service-learning, and Honors College courses. Professor Sendin is the founding advisor of Urbana Literary \& Arts Magazine. Her life's passions are travelling, teaching, and service. 